УДК 349.6(477)

DOI https://doi.org/10.32837/pyuv.v0i2(27).191

\author{
Ю. В. Ковейно \\ старший викладач кафедри права та публічного адміністрування \\ Маріупольського державного університету
}

\author{
В. Д. Дресвяннікова \\ студентка III курсу спеціальності «Право» \\ Маріупольського державного університету
}

\title{
ПРАВОВЕ РЕГУЛЮВАННЯ ЕКОЛОГІЧНОЇ БЕЗПЕКИ
}

3 огляду на європейський вектор розвитку Україна взяла на себе зобов'язання щодо реформування чинного законодавства. Одним із важливих напрямів реформування є сфера екології.

Негативні наслідки аварії на Чорнобильській $\mathrm{AEC}$, високий ступінь забруднення повітря, води, грунту, надмірне зосередження шкідливого промислового виробництва в деяких областях, нераціональне та виснажливе природокористування в сукупності створюють реальну загрозу національній безпеці нашої держави в екологічній сфері та зумовлюють актуальність дослідження.

В умовах сьогодення питання правового регулювання забезпечення екологічної безпеки є актуальними не тільки під час наукових дискусій, діяльності громадських організацій, а також на державному рівні. Отже, зазначені питання потребують вирішення саме у межах правової регламентації екологічних вимог та нормативів.

Правове регулювання екологічної безпеки досліджували B.I. Андрейцев, Г.І. Балюк, А.Г. Бобкова, А.П. Гетьман, В.В. Костицький, М.В. Краснова, Ю.А. Краснова, Ю.С. Шемшученко, М.В. Шульга та інші. Однак на сучасному етапі розвитку питання правового забезпечення екологічної безпеки не втрачає актуальності та потребує вдосконалення у контексті правового регулювання.

Метою статті $є$ обгрунтування пропозицій щодо вдосконалення правового регулювання екологічної безпеки.

Зазначена нами проблема набула більш глибокого та ускладненого характеру, що вплинуло й на зміну термінології. Так, замість поняття «навколишнє середовище» використовується поняття «екологія», яке є більш повним та відображає сутність проблеми, адже зазначене поняття включає в себе не лише охорону навколишнього природного середовища, але і такий важливий компонент, як раціональне використання природних ресурсів $[1$, с. 96]. Так, безвідповідальне використання природних ресурсів (вирубка карпатських лісів, забруднення водних ресурсів, видобуток бурштину тощо) може призвести до екологічної або техногенної катастрофи, що безпосередньо впливає на стан екологічної безпеки держави в цілому.
Згідно зі ст. 50 Закону України «Про охорону навколишнього природного середовища» екологічна безпека визначається як такий стан навколишнього природного середовища, за якого забезпечується попередження погіршення екологічної обстановки та виникнення небезпеки для здоров'я людей, що гарантується здійсненням широкого комплексу взаємопов'язаних екологічних, політичних, економічних, технічних, організаційних, державно-правових та інших заходів [2].

У науковій літературі містяться різні тлумачення екологічної безпеки як правової категорії. На думку А.П. Гетьмана та М.В. Шульги, їі сутність полягає в захисті людини і навколишнього природного середовища від шкідливого впливу; умовах збереження здоров'я людей і забезпеченні сталого соціально-економічного розвитку; балансі розвитку екосистем; діяльності із захисту життєво важливих екологічних інтересів; в тому, що вона є складовою частиною міжнародної екологічної безпеки [3].

Досить широке визначення поняттю «екологічна безпека" дає В.І. Андрейцев. На думку вченого, екологічна безпека є складовою частиною національної і транснаціональної безпеки, тобто це такий стан розвитку суспільних правовідносин і відповідних їм правових зв'язків, за якого системою правових норм, інших державно-правових i соціальних засобів гарантується захищеність права громадян на безпечне для життя і здоров'я довкілля, забезпечується регулювання здійснення екологічно небезпечної діяльності і запобігання погіршенню стану довкілля та інших наслідків, небезпечних для життя і здоров'я особи, суспільства і держави. Така діяльність потребує чіткої конституціоналізації в чинному законодавстві [4].

А.Г. Бобкова вивчає питання забезпечення екологічної безпеки в контексті здійснення екологічного підприємництва, при цьому розглядає напрями правових засад розвитку екологічного підприємництва як умову забезпечення екологічної безпеки [5].

M.I. Малишко розуміє екологічну безпеку як певну діяльність, іншими словами, як систему заходів, спрямованих на захист життєво необхідних інтересів людини від несприятливого впливу 
навколишнього природного середовища, слушно вказуючи при цьому, що екологічна безпека є центральним питанням екології людини, оскільки

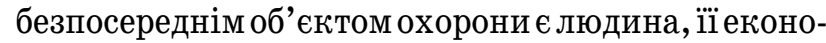
мічні інтереси, екофонд [6, с. 331-335]. Проте, на наш погляд, таке визначення не враховує впливу техногенних чинників, що є особливо актуальним.

Отже, складно виявити єдине і правильне поняття екологічної безпеки. Так, цю правову категорію слід розглядати як стан, за якого життєво важливі інтереси людини, суспільства та держави є захищеними, а для кожної людини гарантується право на безпечне навколишнє середовище та створюються умови, за яких можливий захист довкілля та відтворення природних об’єктів, у тому числі під час здійснення господарської та іншої діяльності.

Ю.А. Краснова вказує на проблеми законодавчого регулювання екологічної безпеки. У її роботі акцентується увага на формуванні належної нормативно-правової бази, спрямованої на стимулювання розвитку діяльності щодо забезпечення екологічної безпеки, на усунення необгрунтованих регулятивних обмежень діяльності суб'єктів у сфері охорони природи та на прозорість нормативного регулювання і наглядових заходів за правовим забезпеченням екологічноїбезпеки тощо [7].

Наголосимо на тому, що, попри очевидний поступ у правовому регулюванні екологічної безпеки, на законодавчому рівні не вирішені усі правові проблеми, які існують у зазначеній сфері та потребують уваги.

Говорячи про джерела правового регулювання екологічної безпеки, варто також вказати на достатньо велику їх кількість. Це зумовлено різними критеріями класифікації та відсутністю єдиного підходу щодо цього. Одними із причин відсутності єдиного підходу є наукові дискусії стосовно правового регулювання відносин з використання природних ресурсів у господарській діяльності залежно від конкретного виду. Так, Б.Г. Розовський вказує на тенденцію до поглинання господарським правом природоресурсного права, на неспроможність ефективного регулювання відносин природокористування в рамках екологічного права $[8$, с. $64 ; 9$, с. 190-191].

А.Г. Бобкова запропонувала концепцію господарсько-правового забезпечення використання природних ресурсів [10, с. 26-28].

Г.Д. Джумагельдієва розглядає природокористування як природоресурсний аспект господарської діяльності. Вона визнає майновими відносини у сфері природокористування між самим суб'єктами господарювання, останніми та іншими учасниками відносин у сфері господарювання і робить висновок, що Господарський кодекс і природоресурсні кодекси співвідносяться як акти загального і спеціального регулювання [11].
Застосовуючи загальні питання теорії права щодо класифікації джерел правового регулювання та орієнтуючись на позицію Ю.А. Краснової, яка є найбільш об'ємною та обгрунтованою, маємо змогу зазначити критерії класифікації джерел правового регулювання екологічної безпеки [7].

Найбільш прийнятними є такі критерії:

- за суб'єктом нормотворення (акти ВРУ, Президента України, КМУ, міністерств, агентств, служб; органів місцевого самоврядування);

- за юридичною силою;

- за напрямом правового регулювання;

- критерії законодавчих актів, що визначають правовий статус і повноваження органів державної влади та місцевого самоврядування у вирішенні питання забезпечення екологічної безпеки;

- критерії законодавчих актів, що встановлюють певні екологічні вимоги щодо безпечного здійснення господарської діяльності;

- критеріїзаконодавчихактів,щоспрямованіна захист навколишнього природного середовища та життя і здоров' я людей у надзвичайних ситуаціях;

- критерії законодавчих актів, що спрямовані на забезпечення екологічної безпеки в окремих сферах господарювання (аграрний сектор, сфера електроенергетики, транспорту, реалізації продукції та товарів, поводження з відходами, будівництво підприємств та споруд, космічна діяльність, гірничодобувна та переробна промисловість тощо). Водночас вказані критерії не є вичерпними.

Характеризуючи зазначені критерії, доцільним вважаємо більш детально зупинитися на їх класифікації за юридичною силою. Так, основним джерелом правового регулювання екологічної безпеки є закони, серед яких провідне місце належить Конституції України. Статтями 16 та 50 Конституції України регулюються одні з найважливіших суспільних відносин у сфері забезпечення екологічної безпеки. Так, стаття 16 визначає обов'язок держави щодо забезпечення екологічної безпеки і підтримання екологічної рівноваги на території України, подолання наслідків Чорнобильської катастрофи - катастрофи планетарного масштабу, збереження генофонду українського народу. У ст. 50 Конституції України зазначено, що кожен має право на безпечне для життя і здоров'я довкілля та на відшкодування завданої порушенням цього права шкоди [12].

Необхідно згадати про те, що першим нормативним актом, що регулював та фактично закріпив принципи екологічної безпеки в нашій країні, була Декларація про державний суверенітет України від 16.07.1990р., яка містила окремий розділ 3 назвою «Екологічна безпека». У цьому розділі зазначено, що Україна самостійно встановлює порядок організації охорони природи та використання природних ресурсів на своїй території, дбає про екологічну безпеку громадян та генофонд 
народу, про молоде покоління, має право заборонити будівництво та припинити функціонування будь-яких підприємств, установ, організацій та інших об'єктів, які становлять загрозу екологічній безпеці [13].

Закон України «Про охорону навколишнього природного середовища» від 25.06.1991 р. є своєрідною екологічною конституцією, адже саме в ньому найбільш повно обгрунтовані основні принципи охорони навколишнього природного середовища, у тому числі зосереджені питання забезпечення екологічної безпеки в країні. Загальні положення у сфері екологічної безпеки закріплені в окремому розділі «Заходи щодо забезпечення екологічної безпеки», в якому статтею 50 визначається поняття «екологічна безпека», а статтями 51-59 висвітлюються вимоги щодо забезпечення екологічної безпеки під час здійснення різних видів діяльності [2]. Як справедливо зазначає Ю. Шемшученко, вищевказаний Закон вже не відповідає реаліям сьогодення. Він базується на концептуальних засадах 1990-х pp. і не забезпечує системної екологізації всіх сфер громадського життя, а тому потребує змін відповідно до вимог сьогодення, зокрема й адаптації до законодавства Європейського Союзу, впровадження багатосторонніх екологічних угод [14].

Главою 6 (ст. 360-366) Угоди про асоціацію України з ЄС регламентується питання співробітництва у сфері навколишнього середовища. У цій главі зазначаються гарантії та умови забезпечення екологічної безпеки та перспективи у вказаній сфері [15].

Заслуговують на увагу також Основні засади (стратегії) державної екологічної політики України на період до 2030 року [16]. У документі зазначені основні проблеми у сфері екології та сучасний стан довкілля. Крім того, вказані причини виникнення екологічних проблем, серед яких виділені основні, які різняться залежно від сфери господарської діяльності або діяльності органів управління та здійснення контролю. Основними 3 них є такі: недосконалість законодавчих та нормативно-правових актів; неефективна система державного управління у сфері охорони навколишнього природного середовища; недостатне фінансування 3 державного та місцевих бюджетів природоохоронних заходів; низький рівень розуміння в суспільстві пріоритетів збереження довкілля та переваг збалансованого (сталого) розвитку через недосконалість системи екологічної освіти та просвіти тощо. Так, вказані проблеми безпосередньо впливають на стан екологічної безпеки та потребують впровадження дієвого механізму правового регулювання забезпечення екологічної безпеки, що передбачений у зазначеній стратегії.

У ст. 6 Закону «Про основи національної безпеки України» чітко визначені пріоритетні на- ціональні інтереси у сфері екологічної безпеки, до яких віднесені такі види діяльності, як забезпечення екологічно та техногенно безпечних умов життєдіяльності громадян і суспільства, збереження довкілля, раціональне використання природних ресурсів [17].

Не менш важлива роль відводиться поресурсовим нормативним актам, які визначають нормативи та ліміти використання окремих природних ресурсів для здійснення викидів та скидів забруднювальних речовин, розміщення відходів, що є умовою забезпечення екологічної безпеки. До поресурсних актів належать такі документи: Земельний кодекс України, Водний кодекс України, Лісовий кодекс України, Кодекс України про надра, Закон України «Про охорону атмосферного повітря» тощо.

Підзаконні нормативно-правові акти також є джерелами права екологічної безпеки і зі своєю складною ієрархією займають відповідне місце. До підзаконних нормативних актів належать такі документи:

- укази і розпорядження Президента України (Указ Президента України №381/2017 «Про додаткові заходи щодо розвитку лісового господарства, раціонального природокористування та збереження об'єктів природно-заповідного фонду" [18]);

- постанови та розпорядження Кабінету Міністрів України, на який покладено обов'язок координації міністерств та інших органів виконавчої влади в реалізації державної екологічної політики відповідно до ст. 116 Конституції України, ст. 17 Закону України «Про охорону навколишнього природного середовища» та Закону України «Про Кабінет Міністрів України» [12; 2; 19]. Серед передбачених законодавством повноважень Кабінету Міністрів України можна виділити забезпечення реалізації державної політики у сфері екологічної безпеки. Одним зі способів реалізації цієї політики є розробка та затвердження відповідних нормативних актів (постанов та розпоряджень). У питаннях забезпечення екологічної безпеки доречно згадати про постанови Верховної Ради України. Серед таких документів провідне місце посідають «Основні напрями державної політики України у галузі охорони довкілля, використання природних ресурсів та забезпечення екологічної безпеки», затверджені постановою Верховної Ради України від 5 березня 1998 р. №188/98. У вказаній постанові акцентовано увагу на незадовільному стані довкілля, причинах його загрозливого стану у промисловості, енергетиці, транспорті, у сільському господарстві, зафіксовано показники накопичення відходів тощо [20];

- накази, інструкції, правила центральних органів виконавчої влади, в систему яких входять міністерства, державні служби, агентства, центральні органи виконавчої влади зі спеціальним 
статусом на чолі з Міністерством екології та природних ресурсів України. Накази Міністерства є обов'язковими для виконання центральними i місцевими органами виконавчої влади та місцевого самоврядування, підприємствами, установами й організаціями незалежно від форм власності, а також громадянами. До таких нормативно-правових актів відносять Наказ Міністерства екології та природних ресурсів України «Про затвердження Порядку обміну документами в електронній формі при видачі дозволу на спеціальне водокористування» тощо [21];

- рішення органів місцевого самоврядування, які в межах своєї компетенції розробляють екологічні програми, організовують збір, переробку, утилізацію і поховання відходів на своїй території, здійснюють регулювання планування i забудови населених пунктів тощо. Перелічені напрями діяльності реалізовуються за допомогою прийняття нормативно-правових актів місцевого значення, які не можуть суперечити вимогам Конституції та законів України;

- локальні нормативно-правові акти. Це джерела організації спеціальних екологічних служб, створених на екологічно небезпечних підприємствах. Їх розуміють як нормативні акти, що приймаються в рамках чинного національного законодавства, правила діяльності суб'єкта господарювання, затверджені належним чином, які мають певну юридичну силу тільки на відведеній їм території, є обов'язковими для виконання усім персоналом і мають природоохоронне і антропоохоронне спрямування.

Наявність проблем забезпечення екологічноі безпеки України дає підстави замислитися над удосконаленням системи екологічного законодавства в Україні в зазначеній сфері.

А.П. Гетьман вдало визначає стан сучасного екологічного законодавства як багатогалузеву систему нормативних актів різної юридичної сили, що ускладнює їх використання та призводить до численних суперечностей між ними або неузгодженості окремих актів, до дублювання. Крім того, наявність нормативних приписів у великій кількості правових актів створює значні труднощі як у теорії так і практичній реалізації [22, с. 173].

Отже, вирішенням проблеми екологічної безпеки є вдосконалення екологічного законодавства в зазначеній сфері, тобто злагоджена та ефективна діяльність державних органів щодо створення законопроектів, метою яких буде урегулювання питань екологічної безпеки, внесення змін та доповнень до чинних нормативно-правових актів, які регулюють окреслену сферу, виконання вимог, ратифікованих Верховною Радою, міжнародних Конвенцій та інших договорів, а також зобов'язань України щодо екологічної безпеки у зв'язку з інтеграційними процесами.
Таким чином, можна виділити певні напрями удосконалення чинного екологічного законодавства, які мають прямий та опосередкований вплив на стан екологічної безпеки в нашій країні. Ці напрями такі: реалізація принципу пріоритету екологічних інтересів над економічними; формування екологічної та еколого-правової ідеології, масової та індивідуальної психології, підвищення еколого-правової культури та освіти громадян, представників органів державної влади та місцевого самоврядування щодо забезпечення екологічної безпеки; узгодженість основних напрямів державної та регіональної політики щодо екологічної безпеки в умовах децентралізації влади; узгодженість і гармонізація екологічного законодавства України в цілому із законодавчою базою Європейського Союзу з урахуванням соціальних, правових та економічних особливостей держави; реформування органів управління в системі політики екологічної безпеки, тобто розподіл повноважень та баланс між гілками влади.

Безсумнівно, екологічна безпека є частиною загальної безпеки і одним з елементів, що формує національну безпеку України. Очевидним є те, що загромаджена система екологічного законодавства з її неузгодженостями, прогалинами, застарілою термінологією та іншими зазначеними нами вище проблемами недостатньо регулює питання екологічної безпеки та потребує застосування принципово нових і ефективних методів систематизації та вдосконалення. Цього можна досягнути у синтезі наукової думки, юридичної практики та з урахуванням вимог законодавства Європейського Союзу. Лише комплексний підхід до зазначеної проблеми дасть бажані результати.

\section{Jimepamypa}

1. Собовий О.M. Особливості змісту екологічної функції держави як необхідної складової забезпечення екорівноваги. Науковий вісник Національного університету біоресурсів і природокористування України. Серія «Право». 2013. Вип. 182, ч. 3. С. 94-99.

2. Про охорону навколишнього природного середовища : Закон України від 25.06.1991р. № 1264. URL: https://zakon.rada.gov.ua/laws/show/1264-12.

3. Екологічне право України : підручник / за ред. A.П. Гетьмана, M.В. Шульги. Харків, 2005. URL: http://www.ebk.net.ua/Book/law/getman_ekopu/ part7/701.htm.

4. Андрейцев В.І. Право екологічної безпеки : навч. та наук.-практ. посіб. Київ : Знання-Прес, 2002. 332 с.

5. Бобкова А.Г. Правові засади розвитку екологічного підприємництва як умова забезпечення екологічної безпеки. URL: http://jlsouk.donnu.edu.ua/article/ view $/ 6770 / 6802$.

6. Малишко M.I. Екологічне право України : навч. посіб. Київ:ВидавничийДім «Юрид. книга», 2001.389c.

7. Краснова Ю.А. Деякі питання визначення джерел правового регулювання екологічної безпеки. Науковий вісник Національного університету біоресурсів і природокористування України. 2014. Вип. 197. Ч. 3. С. 122-131. 
8. Розовский Б.Г. Король жив. Но нуждается в лечении. Чернигов : Десна Полиграф, 2017. 232 с.

9. Розовский Б.Г. "Северный полюс» экологического права. Вісник Луганського державного універси тету внутрішніх справ іл. Е.О. Дідоренка. 2012. № 1. C. $188-200$.

10. Бобкова А.Г. Правове забезпечення використання природних ресурсів у сфері господарювання. Природоресурсне право в систелі права України: історія, сьогодення, перспективи : зб. матеріалів круглого столу, 30-31 жовтня 2015 р. / за заг. ред. М.В. Шульги. Харків : Оберіг, 2015. С. 26-28.

11. Джумагельдиева Г.Д. Хозяйственное использование природных ресурсов в структуре правовых учебных дисциплин. Вісник Донецького національного уні верситету. 2012. № 2. С. 35-41.

12. Конституція України : Закон України від 28.06.1996 p. URL: https://zakon.rada.gov.ua/laws/ show $/ 254$ к $/ 96$-вр.

13. Декларація про державний суверенітет України від 16.07.1990 p. URL: https://zakon.rada.gov.ua/laws/ show/55-12.

14. Шемшученко Ю.С. Актуальні проблеми кодифікації національного та міжнародного екологічного права. Право України. 2011. № 2. С. 4.

15. Угода про асоціацію між Україною, з однієї сторони, та Європейським Союзом, Європейським співтовариством з атомної енергії і їхніми державами-членами, з іншої сторони, в редакції 30.11.2015 року. URL: https://zakon.rada.gov.ua/rada/show/984 011\#n2820.

16. Про Основні засади (стратегію) державної екологічної політики України на період до 2030 року : Закон України від 28.02.2019 року № 2697-VIII. URL: https://zakon.rada.gov.ua/laws/show/2697-19.

17. Про основи національної безпеки України Закон України від 08.07.2018 р. № 964-IV. URL: https://zakon.rada.gov.ua/laws/show/964-15.

18. Про додаткові заходи щодо розвитку лісового господарства, раціонального природокористування та збереження об'єктів природно-заповідного фонду : Указ Президента України від 21 листопада 2017 року № 381/2017. URL: https://zakon.rada.gov.ua/laws/ show $/ 381 / 2017$.

19. Про Кабінет Міністрів України : Закон України від 11.01.2019 р. №794-VII. URL: https://zakon.rada.gov.ua/laws/show/794-18.

20. Про основні напрями державної політики України у галузі охорони довкілля, використання природних ресурсів та забезпечення екологічної безпеки : Постанова Верховної Ради України від 05.03.1998 р. №188/98-BP URL: https://zakon3.rada.gov.ua/laws/ show/188/98-вр.

21. Про затвердження Порядку обміну документами в електронній формі при видачі дозволу на спеціальне водокористування : Наказ Міністерства екології та природних ресурсів України від 19.02.2019 р. № 75. URL: https://zakon.rada.gov.ua/laws/show/z0462-19.

22. Гетьман А.П. Проблеми реформування екологічного законодавства: до питання про створення Екологічного кодексу України. Вісник Академії правових наук Украӥни. 2006. №3 (46). Харків : Право. 2006. C. $172-181$

\section{Анотація}

Ковейно Ю. В., Дресвяннікова В. Д. Правове регулювання екологічної безпеки. - Стаття.

У статті висвітлено теоретичні підходи щодо визначення поняття екологічної безпеки. Запропоновано варіант визначення поняття екологічної безпеки як стану, за якого життєво важливі інтереси людини, суспільства та держави є захищеними, а для кожної людини гарантується право на безпечне навколишне середовище та створюються умови, за яких можливий захист довкілля та відтворення природних об'єктів, у тому числі й під час здійснення господарської та іншої діяльності. Розглянуто критерії класифікації нормативно-правових актів, які визначають питання правового регулювання забезпечення екологічної безпеки. Зосереджено увагу на критеріях класифікації за юридичною силою. Вказано на недоліки забезпечення екологічної безпеки, серед яких головними $\epsilon$ недосконалість законодавчих та нормативно-правових актів, неефективна система державного управління у сфері охорони навколишнього природного середовища, недостатне фінансування $з$ державного та місцевих бюджетів природоохоронних заходів, низький рівень розуміння в суспільстві пріоритетів збереження довкілля та переваг збалансованого (сталого) розвитку через недосконалість системи екологічної освіти та просвіти тощо. Виділено напрями удосконалення чинного екологічного законодавства, які мають прямий та опосередкований вплив на стан екологічної безпеки в нашій країні. Ці напрями такі: реалізація принципу пріоритету екологічних інтересів над економічними; формування екологічної та еколого-правової ідеології, підвищення еколого-правової культури та освіти громадян, представників органів державної влади та місцевого самоврядування щодо забезпечення екологічної безпеки; узгодженість основних напрямів державної та регіональної політики щодо екологічної безпеки; узгодженість і гармонізація екологічного законодавства України із законодавчою базою Європейського Союзу; реформування системи органів управління в системі політики екологічної безпеки.

Ключові слова: екологічна безпека, забезпечення екологічної безпеки, екологічне законодавство, екологічна політика.

\section{Summary}

Koveino Yu. V., Dresvyannikova $V$. D. Legal regulation of environmental safety. - Article.

In the article authors describes theoretical approaches about definitions the concept of environmental safety. Authors offered define the variant of environmental safety as a form which the vital interests of a person, society and the state are protected; the state guarantees for all people the right of environmental safety and create condition when environmental safety and nature regeneration is possible including during business and other activities. Authors described classification of legal acts which regulate the issues environmental security of legal regulation. Question of environmental safety focus on legal force. Limitations of environmental Safety was determined, there are: imperfection of legislative and regulatory acts, ineffective system of public administration in issue of environmental safety, the state have to make a condition for prepare bills which will regulate question of environmental safety, also Ukraine have to do obligatory things which connecting with condition of international agreement, lack off financing from state and local budgets environmental activities, low level understanding to needs safety environment and the benefits of balanced (sustainable) development, imperfection of the environmental education system etc. Marked the directions of acting legislation which have direct and indirect influence on the state of environmental safety in our country, exactly: the principle of priority of environmental interests over economic, created environmental and legal ideology, 
enhancement culture and education level of citizens and officials, main direct of state politics have to respond to regional politics of environmental safety, harmonization of the Ukrainian environmental legislation with the legis- lative base of the European Union, reforming the system of governance in the system of environmental safety.

Key words: environmental safety, providing environmental safety, ecological legislation, ecological politics. 